\title{
Arqueologia da Memória da região (território) de Guarulhos
}

\author{
Alexandre Pianelli Godoy* \\ Cláudia Regina Plens**
}

GODOY, A.P.; PLENS, C.R. Arqueologia da Memória da região (território) de Guaru-

lhos. R. Museu Arq. Etn., 26: 27-41, 2016.

Resumo: $\mathrm{O}$ artigo em questão trata de uma experiência de ensino como pesquisa em Arqueologia Pública dentro do Projeto de Inventário do Patrimônio Arqueológico de Guarulhos desenvolvido entre 2012 e 2014. A Arqueologia Pública é um ramo da Arqueologia que, embora praticada de diferentes modos, visa à interlocução entre a academia e o público acerca dos dados da interpretação arqueológica em uma dimensão intercultural. Portanto, por meio do entrecruzamento entre Arqueologia Pública, história oral temática e memória, procuramos mostrar o modo como as lembranças e as recordações dos moradores da região de Guarulhos se relacionam com os vestígios arqueológicos na concepção e recepção do patrimônio cultural/território da cidade.

Palavras-chave: Arqueologia Pública; História Oral Temática; Memória; Patrimônio.

\section{Introdução}

A longo da história moderna, na concepção ocidental, tem sido creditada aos Estados a proteção ao direito ao patrimônio cultural, assim como os direitos econômicos, cívicos e humanos. Contudo, como ressalta Boaventura de Sousa Santos (1997), o discurso de direitos humanos, de onde advém o direito sobre o patrimônio cultural, carrega em seu âmago diversos problemas, entre eles os mais básicos que concernem aos Estados e a sociedade.

Para o autor, enquanto os Direitos Humanos forem concebidos como globalizados, sobrepondo o jugo ocidental para a proteção dos direitos humanos sobre as demais culturas, a sua abrangência entre as sociedades interna-

(*) Historiador, Professor do Departamento de História da UNIFESP.

$\left.{ }^{* *}\right)$ Arqueóloga, Professora do Departamento de História da UNIFESP. cionais será relativa por esbarrar em concepções de mundo multiculturais. Mais do que isso, são justamente os Estados os maiores violadores desses direitos fundamentais da humanidade, fazendo com que não haja garantia de proteção a esses direitos.

Por outro lado, a sociedade globalizada espera que o Estado proteja seu patrimônio, mas tem dificuldade de encontrar modos de ativamente realizar ela própria participação na proteção de seu legado cultural. Ainda segundo Santos (1997), os direitos de uma sociedade, na concepção ocidental, vêm em contrapartida de deveres que os cidadãos prestam a essa mesma sociedade. De modo que, para o autor, para poder se desprender das amarras da globalização, os Direitos Humanos e o direito ao patrimônio têm de ser forjados no próprio âmago cultural de uma sociedade.

A partir do pensamento de que a população que vivencia a cidade deva participar mais ativamente nos processos que envolvam o reconhecimento de seu patrimônio cultural, 
o projeto Pesquisa e Inventário do Patrimônio Arqueológico de Guarulhos - PIPAG -, iniciou seu trabalho de forma a ouvir o que a população tinha a dizer de seus bens culturais. Essa etapa da pesquisa foi destacada dentro do que chamamos de Arqueologia Pública - AP -, um ramo da Arqueologia que vem sendo praticada de diferentes modos, não havendo um consenso sobre seu conceito.

De modo geral, o que grande parte dos trabalhos e debates acerca da AP tem em comum é a interlocução entre a academia e o público acerca dos dados e interpretação arqueológica. Ela se constitui em um elo fundamental entre a produção do conhecimento acadêmico, a circulação e apropriação dos seus saberes em escala mais ampla e por diferentes esferas de comunicação e sua relação com o conhecimento existente nas comunidades sobre o seu local, sua história de vida, material e/ou imaterial, a que denominaremos de dimensão intercultural.

A AP é parte constitutiva do PIPAG de modo que possa ser produzida pelos sujeitos que também são objetos de estudo. Dessa forma, esperamos que uma parcela da população possa se reconhecer naquilo que participou e seja instada a se apropriar de um conhecimento e de formas criativas de usar seu patrimônio que é, necessariamente, de natureza intercultural, pois "remete à confrontação e ao entrelaçamento, àquilo que sucede quando os grupos entram em relações e trocas (...) implica que os diferentes são o que são, em relações de negociação, conflito e empréstimos recíprocos" (Canclini, 2009: 17), em nosso caso, aos diferentes saberes e práticas das universidades, das escolas e das comunidades.

O inventário do patrimônio arqueológico do ponto de vista científico-metodológico segue parâmetros distintos do "inventário da memória” dos moradores, mas não são necessariamente opostos. A partir da proposta e da realização das entrevistas foi possível perceber as relações entre os materiais e estruturas a serem mapeados e localizados na pesquisa arqueológica e as diversas camadas de sentido que se depositaram nas memórias dos moradores.

Aqui apresentamos uma primeira leitura das vozes dos entrevistados ${ }^{1}$ que nos apontaram algumas direções para o início do projeto, para nos dizer como a população percebe seus bens e seu território.

Com este intuito, selecionamos trechos das entrevistas da Dona Maria Nilza, Sr. João Ferreira da Silva, vulgo "João do Barranco", Sr. Irmo Pierre, Dona Tereza e Sr. Rodolfo, vulgo "Wolf", que gravitaram sobre o modo como impactaram na percepção, concepção, recepção, valorização ou desvalorização do patrimônio do território cultural de Guarulhos.

Todos são moradores da região, possuem acima de cinquenta anos e estão fixados em Guarulhos há pelo menos quarenta anos. De um modo geral, para a história oral de vida, ou que lida com tradições orais, esse número de entrevistados é grande e significativo, porém, quando se trata de uma história oral temática, a quantidade de entrevistados pode variar caso se verifique ausência de temas concernentes aos objetivos de um projeto.

A primeira parte do artigo abordará o relatório descritivo da pesquisa dos Resultados: entrevistadores, entrevistados e seus lugares de enunciação. A segunda parte versará sobre o relatório analítico dividido igualmente em dois momentos: História oral, arqueologia e memória; História oral no projeto: uma arqueologia da memória.

\section{O PIPAG e a sua concepção de Educação Patrimonial}

O PIPAG possui uma dimensão científica baseada na teoria, na metodologia e na pesquisa de campo da Arqueologia Histórica e uma clara dimensão tecnológica ao se utilizar de técnicas que possibilitem, por exemplo, identificar sítios arqueológicos por um sistema

1 Entrevistas resultadas de trabalhos de alunos de graduação do Departamento de História da EFLCH/UNIFESP, sob a orientação da professora e coordenadora do projeto Cláudia Regina Plens (turma de 2012) e de suas respectivas análises sob a orientação do professor colaborador Alexandre Pianelli Godoy (turma de 2014) baseadas na metodologia da história oral temática (Alberti, 2005), isto é, não restrita à história de vida dos moradores, mas atenta ao que "lembravam" e como "recordavam" (Ricoeur, 2007) sobre o patrimônio histórico de sua cidade, dentro da temática mais ampla do PIPAG. 
de radar de modo a facilitar o mapeamento do subsolo que contenha números significativos de materiais e estruturas a serem escavadas com maior precisão e menor impacto ao patrimônio arqueológico.

Essas dimensões da pesquisa acadêmica e aplicada, no entanto, são de difícil acesso e conhecimento do público. São fundamentais para a produção do conhecimento sobre a história de Guarulhos, mas, dificilmente, seus resultados serão consultados pela população local na universidade ou em livros e artigos acadêmicos sobre o assunto. Desta forma, a AP se constituiu num elo fundamental entre a produção do conhecimento acadêmico, a circulação e apropriação dos seus saberes em escala mais ampla e por diferentes esferas de comunicação e sua relação com conhecimento existente nas comunidades sobre o seu local, sua história de vida, material e/ou imaterial, a que denominaremos de dimensão intercultural.

Crescem cada vez mais as pesquisas sobre os usos ou a recepção cultural do patrimônio que são fontes importantes para a dimensão intercultural aqui defendida, pois corresponderia:

aos modos socialmente construidos para a participação da sociedade em geral na identificação, conservação, estudo e difusão dos bens que configuram a sua identidade. Isso implica que a população se sinta identificada com os elementos a serem conservados, que se reconheça neles, para que eles se tornem, de fato, representativos dela e para ela. O reconhecimento do pertencimento coletivo dos bens acarreta esforços comuns para sua conservação e, quanto mais coletivo e representativo eles forem, mais protegidos estarão (Zanirato, 2009: 147).

Nesse sentido, ao invés de nos seduzirmos pela memória e fugir ao seu desafio, optamos por trazê-la como fonte de investigação sobre o patrimônio arqueológico de Guarulhos a partir da colaboração de moradores da cidade que pudessem nos contar sobre sua história de vida e, evidentemente, sobre o que lembravam de como recordavam da história da região e dos seus bens culturais materiais e imateriais. Portanto, concomitante ao processo de investi- gação científico-tecnológica, consideramos que os moradores de Guarulhos detêm um saber específico contidos em suas memórias.

Cabe esclarecer que a concepção de AP do projeto vai além, ou talvez aquém, da perspectiva que investiga a maneira como os sujeitos usam ou recepcionam os bens materiais e imateriais que são considerados por eles ou por outros como "patrimônio". As políticas oficiais de patrimônio tendem a inculcar a importância da preservação e da conservação dos bens, ignorando os sentidos divergentes do termo para as populações, inclusive de suas "resistências" ou "negligências".

Por sua vez, os estudos de recepção estendem o significado do termo de maneira tão ampla, ao considerar as múltiplas visões das populações, que a categoria passa a designar tudo e, ao mesmo tempo, nada. Ou seja, procuramos estar atentos aos problemas dos usos e abusos da memória que sempre permearam o tema do patrimônio e de sua história (Todorov, 2000).

Diante da complexidade da questão, as entrevistas como os moradores da região não foram tratadas apenas como "fontes de informação" para desvendá-las, corrigi-las ou cotejá-las com os vestígios arqueológicos, o que não deixa de ser legítimo. Tampouco como aceitação de tudo o que foi dito como um conhecimento nato ou adquirido que desvendaria a "alma patrimonial" de sua gente, se bem que não ignoramos ali residir um saber sobre sua história de vida material e imaterial.

Por isso, as entrevistas foram abordadas a partir da perspectiva da história oral (Portelli, 2001; 2010) e temática (Meihy, 2005) e das relações intrincadas com a memória, a história e o esquecimento (Ricoeur, 2007), o que trataremos adiante. Dessa forma, acreditamos conferir um tratamento científico dentro dos parâmetros "não-galileanos" do "conhecimento histórico indiciário" (Ginzburg, 1989) e, justamente por isso, considerando a perspectiva dos entrevistados, que serão denominados daqui por diante de "sujeitos-colaboradores" da pesquisa. Portanto, é um modo de tentar dialogar uma concepção de AP e de produção de conhecimento acadêmico como ação educativa e epistêmica intercultural. 
Tendo em vista que a educação patrimonial não nasceu como campo de estudo com configurações epistemológicas próprias, mas dependentes das ações educativas das instituições oficiais de patrimônio tanto na Europa (Choay, 2001) como no Brasil (Horta, Grunberg, Monteiro, 1999) - e mais recentemente com sua apropriação para o turismo (Urry, 2001) é concebida mais como uma metodologia de ação educativa "não escolarizada" (Grunberg, 2007) do que como uma pesquisa que exige o entrelaçamento de diferentes saberes cuja especificidade se dá no ato do "pôr em relação" e não previamente como um receituário a ser reproduzido em todas as circunstâncias.

Entretanto, com o passar dos anos, as justificativas teóricas apareceram e tomaram de empréstimo abordagens que, em sua grande maioria, são da teoria da história e das ciências da educação (Ramos, 2004; Cadernos do CEOM, 2007; Soares, 2007; Azevedo, Catão, Ferreira, 2009; Pérez, Tavares, Araújo, 2009); da psicologia cognitiva (Murta, Albano, 2002); ou da arte-educação (Grinspum, 2000), trazendo muitos benefícios, mas também prejuízos para os que não se enquadrassem nessa ou naquela abordagem. Faltam também estudos sobre essas ações educativas não escolarizadas no Brasil em perspectiva histórica.

Diante do exposto, não pretendemos "inventar a roda" ou lançar moda. No entanto, não concebemos, como deve ter ficado claro, a AP como uma ação de colocar em prática uma "metodologia" que venha ilustrar uma pesquisa acadêmica já elaborada ou para legitimar e/ou divulgar acervos das instituições de patrimônio para atrair visitantes. A AP é um ensino como pesquisa de campo onde participam sujeitos escolarizados, ou não, que interferem nos resultados da pesquisa que ocorre no "campo" do arqueólogo ou no "arquivo" do historiador, enfim, é uma forma intercultural de produção de saberes com suas trocas, conflitos e tensões.

\section{Metodologia}

A AP começa antes da produção de materiais e de metodologias de ações educativas. Ela é produto de uma situação de pesquisa em processo e em ato. Por isso, optamos por envolver os alunos do curso de História da Universidade Federal de São Paulo no projeto, pois já dispomos em nossa grade curricular de diferentes disciplinas para complementação de estudos na área de "História, Memória e Patrimônio". A unidade curricular (disciplina) de "História e educação patrimonial" é uma entre as várias oferecidas: História, memória e patrimônio; História e espaços edificados; História e patrimônio imaterial; História e museus; História e arquivos; Arqueologia Histórica. Além de realizarem atividades em instituições de patrimônio para consolidar os conhecimentos adquiridos.

A coordenadora do projeto, profa. Dra. Cláudia Regina Plens, ficou responsável pela unidade curricular de História e educação patrimonial em 2012 que é, normalmente, ministrada em sistema de rodizio por todos os professores da área de "História, Memória e Patrimônio" e também de "Ensino de História". Com isso, pudemos relacionar melhor o processo de pesquisa do PIPAG com os conteúdos da disciplina de modo que os graduandos percebessem a educação patrimonial como teoria a ser discutida em relação com a prática de pesquisa de campo a ser realizada.

Foi de fundamental importância discutir os conteúdos teóricos da disciplina para a realização da pesquisa de campo que consistiu nas entrevistas com os moradores da região de Guarulhos (sujeitos-colaboradores) e com a transcrição das mesmas como trabalho final. Logo, antes de discutirmos os conceitos prévios de educação patrimonial que norteiam nossa concepção, a prática de ensino na disciplina é que foi a responsável por estabelecer as relações entre teoria, pesquisa de campo e os objetivos do PIPAG.

Em um primeiro bloco de aulas foram discutidos, por meio de textos teóricos, os conceitos de arqueologia (Funari, 2005) e de patrimônio material e imaterial (Martins, 2009; Abreu, Chagas, 2002) e suas relações em conjunto com os objetivos do PIPAG. Os textos citados não traduzem a extensa bibliografia ou o "estado da arte" do campo, mas procuramos selecionar artigos com uma visão mais abrangente, pois nem sempre os alunos tinham domínio dos 
conceitos por se tratar de uma unidade curricular eletiva e que pode ser realizada em diferentes momentos de sua formação.

Em um segundo bloco de aulas, trabalhamos com as diferentes definições de história oral como gênero (Portelli, 2001) e sua relação com a memória e a identidade e a metodologia de pesquisa em história oral temática (Meihy, 2005) para que os alunos pudessem construir um roteiro de entrevista partindo das relações entre cultura material e imaterial dentro dos objetivos do PIPAG. A história oral temática visa entrevistar um sujeito a partir da sua história de vida, mas que também se entrelace com as questões norteadoras de um projeto de pesquisa.

Em um terceiro bloco, foi feita a análise e adequação dos roteiros das entrevistas, bem como a marcação e realização das entrevistas com os sujeitos-colaboradores previamente escolhidos mediante sua disponibilidade de data, horário e local, por isso, nem sempre foi possível realizá-las em um mesmo período. Evitamos também padronizar demais as questões, pois os sujeitos-colaboradores possuíam diferentes trajetórias de vida. No entanto, acordamos nos seguintes aspectos:

- O entrevistado deve autorizar a entrevista por meio de carta de anuência; As primeiras perguntas devem possibilitar conhecer o entrevistado;

- As perguntas subsequentes devem contemplar os temas e objetivos centrais do PIPAG: a relação entre cultura material e imaterial;

- As perguntas não devem ser extensas e tampouco direcionar a resposta;

- Outras perguntas podem surgir no decorrer da entrevista desde que pertinentes ao tema do PIPAG;

- Marcar entrevistas com antecedência e onde for mais conveniente ao entrevistado;

- Utilizar gravador digital de alta definição (hi-fi) e verificar o bom funcionamento da aparelhagem antes da entrevista;

- Chegar com antecedência ao local da entrevista;

- Seguir o roteiro de questões proposto e não exceder em uma hora de entrevista;
- Transcrição da gravação e transcriação para reescrever a entrevista de modo que fique compativel com um texto escrito;

- O entrevistado deve ler a transcriação e: conferir, aprovar, alterar ou cortar trechos que considere inadequados;

- Finalmente, o entrevistado deve assinar o seu "de acordo" para o uso no PIPAG por meio de carta de aprovação.

O processo de transcrição/transcriação das entrevistas é longo e exige atenção e rigor. Dessa forma, consideramos que o fato de chegarem ao final desse processo e com as leituras que acompanharam a orientação dos roteiros de questões se constituía em um trabalho suficiente como avaliação da unidade curricular. Portanto, para a história oral, a entrevista é mais do que um mero questionário informativo ou descritivo que possa ser tabulado, mas que possibilite conhecer e documentar a história de vida do entrevistado com as questões do projeto, articulando memória individual, memória social e a história de uma coletividade. O critério de seleção dos entrevistados foi a de que todos pertencessem às diferentes localidades de Guarulhos e que tivessem fixado moradia na região em tempo suficiente para que suas memórias pudessem ser significativas para as questões do projeto. Como exemplo, segue um roteiro de entrevista elaborado pelos alunos:

Roteiro de entrevista com Dona Nilza Matias (vizinha da Igreja do Bonsucesso)

1) Nome Completo:

2) Idade:

3) Qual a origem da sua família?

4) Você sempre morou neste bairro? Em caso negativo: em quais lugares você morou? $\mathrm{O}$ que você se lembra desses lugares?

5) Houve muitas modificações? Se modificou, o que mudou em relação aos espaços naturais?

6) Existia alguma atividade que você praticava nesses lugares e que você não pode mais praticar devido às modificações do lugar?

7) Qual era a rotina da sua família? 
8) Que lugares frequentavam? Havia festividades ou ainda existem festividades locais? Onde? 9)Você conhece a origem e os significados dessas festividades? Que histórias você já ouviu falar sobre esses eventos?

10) Você tem conhecimento se esses eventos são tradições locais?

11) Você pratica ou praticava alguma religião? Onde ficava o lugar? Ainda existe? Caso não exista, o que há no local?

12) $\mathrm{O}$ que você sabe da História de Guarulhos? O que as pessoas falavam da história do município?

13) O que você sabe sobre a história do bairro onde mora?

14) Você se lembra de lugares antigos que fossem próximos (ou não) ao local onde mora?

15) Existe alguma lenda local ou alguma história que as pessoas contam sobre esses lugares?

16) Há lugares que as pessoas que você conheceu evitassem ir? Quais? Por que as pessoas não iam lá?

17) Você sabe, ou já ouviu falar, como as pessoas de um período anterior se relacionavam?

18) Você sabe se essas pessoas deste período conviviam com índios ou escravos?

19) Existe algo em Guarulhos que você se identifique? Que é importante para você? 20)Existe algum lugar que represente ou que seja uma referência para a história local? 21) Seus filhos e netos perguntam ou possuem curiosidade sobre a história do bairro ou de Guarulhos? Eles perguntam a você de sua história ou da história de sua família?

\section{Entrevistados, entrevistadores e seus lugares de enunciação}

Além da entrevista com a Dona Maria Nilza, entrevistamos: João Ferreira da Silva, vulgo "João do Barranco", Irmo Pierre, Dona Tereza e Rodolfo, vulgo "Wolf". Todos são moradores da região, possuem acima de cinquenta anos e estão fixados em Guarulhos há pelo menos qua- renta anos. De um modo geral, para a história oral de vida, ou que lida com tradições orais, esse número de entrevistados é grande e significativo, porém, quando se trata de uma história oral temática, a quantidade de entrevistados pode variar caso se verifique ausência de temas concernentes aos objetivos de um projeto.

Todavia, a leitura do material transcrito revela aspectos extremamente ricos para o inventário do patrimônio arqueológico de Guarulhos. São memórias que tratam de dois processos que se repetem tematicamente na vida desses moradores: a cidade de Guarulhos como um meio ao mesmo tempo rural e urbano, isto é, ora permeado por lembranças da terra e de seus costumes, ora da industrialização do solo e de desenraizamento; ora das variações que indicam mobilidade compulsória por se tratar de um lugar de busca por melhores condições de vida; ora da fixação e do aprendizado de gostar e de viver no lugar, ou seja, de acolhimento e identificação.

Em nosso entender, essas memórias traduzem as relações entre urbano/rural e mobilidade/fixação dentro do que Valderez A. da Silva denominou de "paulistas em movimento" no seu artigo sobre as bandeiras, as monções e as tropas que desde o século XVIII marcaram o processo de ocupação e exploração do solo em uma extensa região:

A chamada Paulistânia, a região expandida a partir de São Paulo, hoje contida em parte dos territórios de Minas Gerais, Goiás, Tocantins, Mato Grosso do Sul e Paraná, vem comprovar os efeitos desse fenômeno. Essa é a face inegável da questão, ou seja, a de que o povoamento e o engendramento de uma vida econômica estável para essas regiões resultou, ao menos em grande parte, dos afluxos iniciais de paulistas para as mesmas (Silva, 2008: 55).

Os entrevistados, evidentemente, estão bem distantes desse processo histórico, mas estão bem próximos quando se trata de representá -los em suas memórias, visto que realizaram um processo inverso de deslocamento desses estados para a fixação em lugar que foi por muito tempo considerado como "franja metropolitana" ou da "Grande São Paulo", cujo processo de 
urbanização e industrialização tratou de apagar pela conurbação populacional, mas não da visão periférica sobre o local. Para um dos entrevistados, por exemplo, o senhor Irmo, tal situação se repete em escala micro entre as regiões centrais da cidade de Guarulhos e os mais longínquos como o Bairro dos Pimentas, onde está localizado atualmente o nosso Campus da UNIFESP:

Aluno: Pra finalizar, você falou que não tinha nenhum caminho, né, que era tudo mato. Qual que era o trajeto que as pessoas pegavam pra ir até a igreja do Bonsucesso?

Sr. Irmo: Era a Juscelino Kubistchek. era um trilho ...

Aluno: Uma trilha...

Sr. Irmo: É, era uma trilha. E se você saísse daqui pra você ir pra São Miguel, ou você pegava a mesma trilha, ou então você saía pelo Jurema que era só mato, entrava nas trilhas também, né, e descia, saía no Parque São Miguel e saía lá na ponte dos Pimentas.

Aluno: Então a Juscelino era uma trilha só?

Sr. Irmo: É. Era uma trilha só. Praticamente que nem hoje, só que era coberto de mato dos dois lados, mas a... a largura dela não modificou em nada. Ali que eu falei da infraestrutura agora a pouco pra trás aí, sobre os prédios, sobretudo que veio pra cá, e nós não temos a infraestrutura, nós não temos o planejamento de nada. A realidade é essa.

Aluna: Tem uma questão que me intrigou bastante, foi quando o senhor falou da... dos indios, né, que eles foram expulsos e tudo. E que... Você falou que o problema que eles sofreram foi o mesmo que a população ainda vive hoje. E qual seria esse problema? Seria a discriminação?

Sr. Irmo: Discriminação! É a discriminação e queira ou não queira é assim, oh... sabe, é... Como eu sou uma das pessoas que, talvez um dos únicos, que tá vivo aqui até hoje, e... vivi tudo isso e participei, porque eu participei, en fui presidente da sociedade, fui presidente de clube, fundei o clube de futebol, fui candidato três vezes, fui diretor de Pais e Mestres das escolas... Então, eu participei muito com a população, e sempre vi que a discriminação nossa, da nossa área era muito grande e isso eu falava dentro da prefeitura, eu nunca tive medo de nada, nunca. E hoje eu vejo pessoas que não têm nada a ver com isso daqui tá lá em cima, sabe? Sabe, chega de queixo erguido. Mas não sabe nada. Se você perguntar pra ele quantos $\mathrm{km}^{2}$ tem Guarulhos pro prefeito de Guarulhos, ele não sabe. Eu sei! Eu perguntei pra um deles um dia, e ele falou Você sabe? Falei - Sei. - Quanto tem? Eu falei - Não sou seu professor, quem tem que ensinar é você. Eu não tenho que ensinar ninguém. Eu sei. Você que aprende. A realidade é essa.

Nesse artigo, apresentamos um dos aspectos mais interessantes do trabalho com a história oral, que é a sua multivocalidade como gênero discursivo (Portelli, 2001). São diferentes vozes que se mesclam: a do passado e a do presente, dos diferentes sujeitos que atravessaram a história de vida dos moradores e também entre entrevistadores e entrevistado. Ou seja, mesmo em uma situação de diálogo, "entrevisões", as vozes revelam as diferentes posições que um sujeito ocupa e ocupou na sua vida e dos próprios alunos no processo de entrevista. Lugares de falas ou de "espaços de enunciação de vozes", no dizer do historiador Michel De Certeau (1994).

Nessa entrevista, fica claro que os alunos foram bastante diretivos em suas questões, apesar do que foi lido e acordado em sala de aula e nos cuidados que devem ser tomados para não inibir/coibir o entrevistado de modo a confundir uma entrevista como um "inquérito" e transformar os sujeitos-colaboradores em "depoentes” de um "interrogatório” (Portelli, 2010: 77). Durante a entrevista, os alunos seguiram o roteiro proposto em sala de aula dentro dos objetivos temáticos do projeto, mas se mostraram tão ansiosos em realizar a atividade que não se deram conta de que o modo de fazer as perguntas (entonação) foi muito diretivo e visando obter "informações" a todo custo. Diante disso, o Senhor Irmo fazia breves silêncios quando não sabia ou lembrava-se de algo, como se dissesse "não posso colaborar", seguido de certo constrangimento dos alunos-entrevistadores com a demora em retomar ou seguir para outra questão. É uma situação de espelhamento entre quem está aprendendo a pesquisar e de quem deseja colaborar, mas com receio de que a entrevista não seja útil para a pesquisa. Há um 
jogo de expectativa de ambos os lados, principalmente do entrevistado que se preocupa com as reações do entrevistador.

A entrevista não foi feita na casa do Senhor Irmo, mas dentro do campus universitário, pois os alunos do período noturno do curso de história da UNIFESP têm dificuldades de se deslocarem para outras localidades da cidade de Guarulhos depois de um longo percurso entre sua casa, o trabalho e, finalmente, para o campus universitário.

O local da entrevista também pode ser determinante para o tipo de lembranças e informações que o entrevistado se dispõe a conceder, assim como o fato de ser entrevistado por universitários, o que reforça constrangimentos, mas também pode resultar em respostas prontas para agradar ou mesmo que envolvam conflitos recentes em que várias vozes se encontram em torno de um problema social ou coletivo. Esse é o caso, por exemplo, do atual debate sobre as condições de infraestrutura do campus e sua permanência no Bairro dos Pimentas, que se espelha na preocupação do entrevistado em mostrar como a localidade e seus habitantes sempre foi "discriminada".

O que queremos ressaltar não é a fragilidade metodológica, se bem que alguns aspectos podem ser evitados, mas o que constitui a força da história oral, isto é, a circunscrição entre entrevistador e entrevistado, sem a qual nada a diferenciaria de um simples questionário e/ou interrogatório. É um momento em que os espaços de enunciação de vozes nos permitem entender que a expulsão dos índios de Guarulhos em um passado remoto da região, onde tinha "só mato", a urbanização da cidade em um passado mais recente, o processo de fixação do Senhor Irmo no Bairro dos Pimentas em um passado mais próximo e o isolamento da localidade em relação à cidade de Guarulhos estão interligados com questões atualíssimas da vida dos alunos com os problemas de infraestrutura do campus e de sua presença no bairro.

O mesmo processo pode ser percebido em todas as entrevistas, mesmo naquelas em que os entrevistadores foram mais empáticos com o entrevistado que, por sua vez, se sentiu mais à vontade em "dizer" sobre as tradições longínquas da região. Dona Teresa, ao se lembrar da Festa de Nossa Senhora do Bonsucesso e do ritual da carpição da terra, fala de "seu" lugar de enunciação/região/religião ao outro. Formam-se, enfim, espaços de escuta mútua entre diferentes lugares de enunciação:

Dona Teresa: ahn eles foram na minha casa e eles queriam fazer o porque da terra e... essa história da terra ai também não é história, foi uma coisa verdadeira, é... Tinha a igrejinha e não era assim modernizada como tá hoje, né? A praça, tudo era diferente, tinha duas ruas assim e... As pessoas vinha, tinha festa, era no mês de agosto, hoje em dia eles deixam pro último domingo porque todo mundo trabalha, né? Mas na época, como só tinha os sitiantes, os fazendeiros em volta, eles faziam no dia quinze de agosto podendo cair em dia de semana dia que fosse. Então uma semana antes todo mundo vinha carpir em volta da igreja porque era só mato aí então tinha gente que fazia promessa pra Nossa Senhora, não sei até onde era verdade isso daí, né? E um homem falou que ele ia carpir que ele queria ficar bom que ele tinha problema na perna e ele foi com tanta fé porque tudo que acontece na vida da gente eu acho que é a fé que faz isso, né? E ele se curou carpindo, então eles carpiam, ajuntavam a sujeira e transportavam pro outro lado pra deixar o pátio bem bonito né? E se curou e ficou esse negócio de carpição, vamos carpir, fazer a carpição pra festa e ficou e virou uma coisa de religião mesmo, eles vêm carpir pra...

Aluno: pra se curar...

\section{História oral, arqueologia e memória}

\section{As memórias do Senhor Irmo e Dona}

Teresa, por exemplo, contêm múltiplas camadas temporais que só podem ser descobertas com uma lenta e delicada escavação da história oral para diferenciar seus "objetos mnésicos", que nos permitem verificar as ocorrências do passado por meio das lembranças afetivas e de suas "anamneses topográficas" que, por sua vez, nos permitem verificar as recorrências de explicação que interligam o passado no presente por meio da recordação reflexiva. 
Para Paul Ricoeur, tal distinção entre a memória-lembrança e a memória-recordação é correlata entre o ato de habitar e o de construir:

As lembranças de ter morado em tal casa de tal cidade ou de ter viajado tal parte do mundo são particularmente eloquentes e preciosas; elas tecem ao mesmo tempo uma memória íntima e uma memória compartilhada entre pessoas próximas: nessas lembranças tipos, o espaço corporal é de imediato vinculado ao espaço do ambiente, fragmento de terra habitável, com suas trilhas mais ou menos praticáveis, seus obstáculos variadamente instransponíveis; (...) Quanto ao ato de construir, considerado como uma operação distinta, ele faz prevalecer um tipo de inteligibilidade de mesmo nível que aquele que caracteriza a configuração do tempo pela composição do enredo (Ricoeur, 2007: 157-9).

Retomando o trecho das memórias de Dona Teresa, o que marca sua lembrança da Festa de Nossa Senhora do Bonsucesso é que "essa história da terra é verdadeira" e que também "não foi história”, ou seja, continua a ocorrer no tempo e não precisa ser contada por meio dos livros e da escrita-erudita. A terra é habitada, abençoada, dita e "bendita". Já a "história" recordada foi construída tal como "a igrejinha e não era assim modernizada como tá hoje". Uma história "é" a da habitação da memória-lembrança, outra história "foi" construída como memóriarecordação.

Esses dois fenômenos mnemônicos não estão separados na narrativa oral com clareza e devem ser analisados com acuidade, de modo que se possam diferenciar as primeiras camadas de objetos mais antigos e frágeis da lembrança daquelas camadas mais superficiais da recordação que tendem as nos convencer do fim da escavação. Tal é a estrutura do solo arenoso e, às vezes, britado, do testemunho oral que:

\section{(...) consiste no fato de que a asserção} de realidade é inseparável de seu acoplamento com autodesignação do sujeito que testemunha. Desse acoplamento procede a fórmula típica do testemunho: eu estava lá.
O que se atesta é indivisamente a realidade da coisa passada e a presença do narrador. Nos locais de ocorrência. E é a testemunha que de início se declara testemunha. Ela nomeia a si mesma. Um triplo dêitico pontua a autodesignação: a primeira pessoa do singular, o tempo passado do verbo e a menção ao lá em relação ao aqui. (...) A autodesignação se inscreve numa troca que instaura uma situação dialogal. É diante de alguém que a testemunha atesta a realidade de uma cena à qual diz ter assistido, eventualmente como ator ou vítima, mas, no momento do testemunho, na posição de um terceiro com relação a todos os protagonistas da ação.

Essa estrutura dialogal do testemunho ressalta de imediato sua dimensão fiduciária: a testemunha pede que lhe deem crédito. Ela não se limita a dizer: "Eu estava lá", ela acrescenta: "Acreditem em mim". A autenticação do testemunho, a partir desse instante, está não apenas autenticado, ele está acreditado. É o credenciamento, enquanto processo em curso, que abre a alternativa da qual partimos entre a confiança e a suspeita (Ricoeur, 2007: 172-173).

A dimensão fiduciária do testemunho oral é o que legitima utilizá-lo como um documento para a história oral sem o qual não haveria nenhuma distinção entre a ficção e a história ou a imaginação e a memória, pois "os falsos testemunhos (...) só podem ser desmascarados por uma instância crítica cujo único recurso é opor aos testemunhos tachados de suspeitos outros testemunhos mais confiáveis. (...) o testemunho constitui a estrutura fundamental de transição entre a memória e a história" (Ricoeur: 401). Essa dimensão da memória torna possível coligir seus fragmentos com outros documentos utilizados pelo historiador e dos vestígios materiais da investigação arqueológica. Por seu turno, é preciso tomar cuidado quando a memória-recordação do entrevistado traz explicações tão prontas e bem amarradas que tendem a seduzir os pesquisadores:

Rodolfo: Ok, bom, é... Meu nome de batismo é Rodolfo, como eu falei anteriormente, eu 
adotei o pseudônimo de Wolf há uns doze anos, então vai ser meio difícil a gente se relacionar por Rodolfo, se você sair perguntando pelo Rodolfo ninguém sabe quem é. Até minha família, meus filhos já acostumaram com isso também, então hoje é menos difícil lidar com o Wolf, até porque é, é, facilita até o diálogo. Curioso isso, você consegue se identificar mais rápido com as pessoas hoje, com um pseudônimo, do que com o nome próprio, mas tudo bem. E eu vim pra cá em 1967 já com três anos de idade. O que trouxe minha família pra essa região é o que leva qualquer família de baixa renda a uma região afastada, que é o poder de aquisitivo. Que até então nós morávamos, nós ficamos pouco tempo em São José dos Campos, que é onde eu nasci, saimos de São José dos Campos, viemos para São Paulo morar na Zona Norte, onde certamente o aluguel era muito alto, meu pai precisava tomar uma atitude de comprar uma casa, e aí que acontece, tem pouco dinheiro, você vai procurar numa distância maior, até chegar aqui, que é onde ele começou a encontrar os terrenos mais baratos pra gente morar e eu posso usar o mapa? Então eu fiz esse mapa justamente pra dar uma ideia da questão imobiliária. Isso é uma continuação, então meu pai, a gente chegou aqui, saiu da Dutra, encontrou o corretor que ficou morando quase trinta anos nessa região. Descemos um pouquinho à rua até aqui, ai ele mostrou um terreno pro meu pai aqui, "ah legal bacana, nós gostamos do terreno, quanto?" meu pai "tanto", "ainda não". Aí ele foi pra dentro do bairro, afundando pra dentro do bairro, até chegar a um quilômetro e meio de distância da, da Dutra. Era esse terreno aqui, né? Meu pai falou "ah então vai ser aqui, vamos comprar esse terreno, e vamos encontrar um lugar pra ficar, enquanto a gente não se estabelece, né?". Usando a foto aqui, esse é o terreno, depois vocês certamente em uma edição mostrar pra o pessoal. $\mathrm{O}$ terreno que meu pai comprou enquanto meu avô que tá aqui construía a casa, nós fomos morar nessa casa aqui da avenida principal do bairro, né? Hoje é um bar, onde eu morava, o cômodo onde eu morava hoje é um butequinho né? É um bar. E aqui é a família a primeira família com quem nós tivemos contato, é... Que são compadres do meu pai até hoje né, e eu tô aqui sentado, então, depois eu mando uma foto mais clara, tô sentado com esse grupo de pessoas aqui em 1967. Então, quer dizer, o que trouxe o meu pai pra cá foi a questão da possibilidade do (...) "efetivo" dele permitia que ele comprasse aqui. Poderia ter sido no fundão de Diadema, no fundão de Carapicuiba, Itapevi, Perus; ia ser a mesma situação, coincidiu de ele vir pra Guarulhos, porque ele teve um primeiro desejo de morar no parque $\mathrm{CE}$ CAP, é... Minha mãe não gostou muito da ideia na época, pelo que eu me lembre, então acabou vindo pra cá, foi o que nos trouxe pra cá. E vivemos nesse, nesse ínterim, levei vida de menino de fazenda literalmente porque não tinha água, não tinha luz, era lampião de gás, era lamparina, né? Aqui bem em frente, riacho, havia um riacho limpinho, lindo, que hoje é um córrego podre que passa aqui. E eu brincava, pescava, batia uma peneira, pescava peixe, tinha um pomar. Então foi uma vida literalmente de garoto de fazenda, até os anos 1974, 1975, e aí começa a chegar muita gente, com essa chega$\mathrm{da}$, as carestias sociais, falta de saneamento, a violência, chegou tudo junto. De 1976 até 1984, aí eu tive nesse período mais ou menos uns quinze, dezesseis amigos assassinados, só de formatura assim três, de oitava série. No total dezenove assassinatos, todos assassinados, né? Quer dizer, a violência pegou firme ali de 1976 até 1984 , mais ou menos.

Rodolfo é o entrevistado com maior loquacidade. É estudante do campus Guarulhos da UNIFESP. Percebe-se por sua narrativa a construção de uma lógica discursiva semelhante àquela encontrada na cultura letrada, nos livros, enfim, tudo aquilo que também é fruto de seu estudo e esforço intelectual, embora sejam inegáveis os sons e as marcas de oralidade que constitui a natureza do documento coletado. Do ponto de vista do historiador e do arqueólogo, é muito interessante quando traz elementos de sua vida de "garoto da fazenda" para entender os contrastes sociais com o processo de urbanização da cidade de Guarulhos.

O fato de a região trazer fortes características de um mundo rural de um "garoto da fazenda" são indícios claros, por exemplo, de que materiais podem ser procurados ou encontrados no leito ou nos arredores de córregos que outro- 
ra foram riachos. Ali podem existir objetos de pesca da época colonial, materiais para extração de ouro, bem como utensílios utilizados para a preparação de alimentos de diversos períodos. É sabido que a região também concentrou grande número de olarias, cuja qualidade e/ou quantidade de matéria-prima do leito dos riachos deve ter favorecido a atividade. Evidentemente, tudo isso são hipóteses, mas podem ser investigadas em camadas profundas e mais superficiais do solo e da memória dos moradores.

Todavia, é preciso desconfiar das marcações temporais do processo de urbanização da região, das datações ou das explicações "extremamente" precisas que delimitam o tempo da "vida na fazenda" e o tempo da "chegada das carestias sociais". Muito provavelmente são tempos que mais se interpenetravam do que se dividiam em marcos temporais precisos. Até mesmo a classificação entre "rural" e "urbano" é movediça por ser uma região de migrações e de mobilidades em que o mundo das cidades e o mundo dos campos podiam se encontrar com frequência.

Há nostalgia do passado rural nas memórias de Rodolfo frente ao mundo urbano violento e desigual que é percebido na sua recordação reflexiva de que seu pai mudou para uma "região afastada" por causa do "poder aquisitivo" e da "possibilidade do seu efetivo", uma explicação sociológica que dificilmente o "garoto da fazenda" iria se preocupar quando "brincava, pescava, batia uma peneira, pescava peixe [e] tinha um pomar" de sua lembrança emotiva. A interpenetração de camadas do rural e do urbano, dos bens materiais e imateriais, da mobilidade e da fixação são os "objetos" de maior valor para o projeto de educação patrimonial do PIPAG, transformada em "metáfora viva" da história oral contida nas memórias de seus moradores:

Rodolfo: (...) Então ah, ah, ah, falou de arqueologia? Aqui pra dentro acima do terreno era um barranco enorme, e nós fomos tirando esse barranco ao longo dos anos, era muita terra. Passamos vinte anos tirando terra do terreno. E numa dessas, nessas retiradas de terra, eu encontrei uma moeda de 1828 que tá comigo até hoje, eu tenho ela guardada, essa moeda, se quiser também que eu fotografe e mande ela pra vocês. Ela saiu dessa, dessa tira de terra, do, do, do terreno, eu dei aquela cavocada, senti um barulho e falei o que é isso? Ai eu entrei em desespero, "pô" uma moeda cara? Eu falei, tem mais. Meu pai adorou aquela moeda porque eu fiz um serviço enorme pra ele né, só tinha ela, e eu fiquei cavando dias seguidos achando que, que ia encontrar mais moeda, mas, não, só tinha aquela mesmo!

\section{História oral no projeto: uma arqueologia da memória}

A história e a arqueologia são ciências que diferem das memórias dos moradores, mas não podem ser colocadas em escala de valor hierárquica de conhecimentos. Bom exemplo disso é que a história é também um tipo de memória, mas uma memória escrito-erudita, que se serve dos documentos previamente alocados/ organizados em um arquivo, inclusive orais, da compreensão/explicação da documentação teoricamente orientada e da representação literária, ou, se quiser, escrita, para a composição da narrativa historiográfica (Ricoeur, 2007). A história é uma recordação escriturária que pode ou não reforçar usos e abusos da memória.

É trabalho do historiador, quando lida como memórias orais, considerar tanto sua confiança na dimensão fiduciária que as tornam um documento em potencial para seu uso na pesquisa como a sua desconfiança na dimensão de reconstrução da recordação. Assim como os historiadores também confiam e desconfiam da recordação escriturária de seu campo de pesquisa, como novos documentos, informações ou interpretações. É, portanto, necessário uma arqueologia da memória, isto é, de diferentes e contrastantes saberes e práticas de sujeitos/lugares sociais para que ocorra um processo de AP menos informativo-cultural e mais formativo-intercultural.

Para isso, as memórias orais devem ser disponibilizadas ao público a partir do tratamento da história oral e da relação com a investigação arqueológica para que possam ser contextualizadas. A "moeda do seu Rodolfo" é um bom exemplo de como podem ser aproveitados tanto o potencial informativo como formativo das memórias dos sujeitos-colaboradores na troca, conflitos e confrontos de saberes/práticas. 
A moeda deve ser avaliada pela arqueologia de modo que possam surgir explicações sobre o seu aparecimento naquele terreno e que nos contam sobre os processos de deslocamentos, migrações e fixações de sujeitos na região ao longo do tempo. Porém, não é apenas o potencial informativo do objeto que interessa à AP, mas também a história de vida que envolveu o achado do vestígio. Nela se pode perceber que os moradores da região revolveram a terra do barranco para que pudessem ter melhores condições de habitação e sobrevivência. São histórias de movimentações-fixações que estão soterradas e que devem ser escavadas. A moeda é tão preciosa quanto o processo de mudança que envolveu sua descoberta e que também pode ser cotejada com outras entrevistas de modo a ter uma visão mais ampla e contextualizada das camadas da memória de onde podem surgir outras "histórias":

João: Ó... Eu vou contar uma historinha para a senhora, acredita quem "quere". Eu sempre falo assim. Ó... Aqui quando era a estradinha, estradinha estreitinha, (som baixo) essa estrada a pessoa podia dormir uma noite aí, cansei de ver bêbado amanhecer deitado no meio da estrada, do sábado para o domingo, porque não passava um carro, porque... até hoje não anda muito carro aí... depois das dez horas, a turma não gosta de rodar nessa rodovia, ai começa quatro horas os caminhão de lenha rodar, mas assim a noite todinha o pessoal não gosta de andar, mas naquela época não andava mesmo, naquela época que não tinha asfalto, $e$ os bêbados, o povo não andava mesmo, cansei de ver bêbado e não passava nenhum carro. E diziam... Quem contou isso foi um preto velho, um senhor... Ele falava assim, ô João... Toda sexta-feira diz que subia uma procissão, a senhora sabe o que é uma procissão, né?

Aluna: (Interrupção) sei...

João: ... aquela turma rezando, cheia de vela, meia-noite, diz que a procissão começava naquela primeira lombada que a senhora vê lá... Diz que começava de repente, cheia de gente, diz que tudo rezando, diz que andou... Quando a procissão chegava naquele alto diz que acabava. Toda sexta-feira, essa procissão começava lá e quando todo mundo com vela rezando e quando chegava naquele ponto sumiam, diziam que eram as alma, principalmente dos escravos.

Aluna: Mas agora ninguém mais vê?

João: Não, não, não... Ó... Vai falar assim, isso é mentira, é lenda, não é mesmo? Pode ser mentira, pode ser lenda. Mas que contava, contava, sim. Mas essa do padre é bom acreditar, viu... A casa velha, antiga, o dono, o seu Miguel Piorelli, era um italiano sério, viu, não era de mentira, não, viu, ele contava para mim, porque naquela época não tinha luz até aqui. Essa rede elétrica, que eu me lembro, não tinha luz. E o que acontece? Ele contando para mim, eu, o antigo dono, um dos donos. Aquela sede era do tempo dos escravos, mudou... e... e... a estrutura, mas envernizaram toda a casa, mas era a sede velha, e quando ele comprou, ele continuou e quando ele vinha de Guarulhos, ele morava em Guarulhos, ele ficava na sede velha, ele disse que ouvia de noite, ele disse que jantou sozinho, jantou, ai ele diz que lavou o prato, diz que colocou lá na prateleira. A casa tinha três cômodos, era aqueles de assoalho, você sabe (som baixo) não era taco, era assoalho. E ele... E ele só tinha uma caminha naquele quarto, aquelas caminhas de armar e fechar e tinha rodinhas, aquela caminha, ele esticou a caminha, diz deitou e diz que com a vela acesa do lado dele, falou, daqui a pouco eu apago a vela, de repente chegaram e fizeram na vela "fu", ele falou mas vento não tem, ele pegou o isqueirão, "pó", acendeu a vela, tornaram a chegar e "fu", diz que três vez, ai diz que se invocou, aí disse vamos dormir no escuro. Pegaram a caminha dele e começaram, no escuro, vim lá e vim cá, ele disse que se invocou, levantou, pegou dois tijolos, travou a cama, e falou agora eu quero ver empurrar,... e falou que começou a destelhar a casa, subiram em riba e começaram a jogar as telhas...ai diz que começaram a quebrar os pratos dele tudo, e ele disse que amanhã não tem nem uma xícara pra tomar café, e diz que foi até quando o galo cantou, quando o galo cantou acalmou. No outro dia, ele disse que a telha tava no mesmo lugar, o telhado... os pratos no mesmo lugar. Ele cansava de contar isso. Outra vez ele disse que foi... lá tinha uma bica d'água... e ele disse que jantou e foi lá lavar o prato na bica...quando ele abriu a porta ele disse 
que tinha um "puta" de um crioulo só de calção e ele disse que nó... ele disse que nesse dia ficou com medo, disse que fechou a porta e entrou pra dentro... ele falou João eram as almas... era uma alma dum negrinho (som baixo) escravo, ele cansava ô... nós sentava lá e ele ficava me contando, e... aquele eu acredito não era senhor de mentira....Agora são coisas que tem gente que acredita e tem gente que não acredita.

As histórias de assombração fazem parte do repertório de muitos sujeitos que são entrevistados pelos historiadores da oralidade. São uma fonte importante para se entender esse processo de permanência/mudança temporalterritorial que envolveu a formação da região de Guarulhos, bem como o universo urbano-rural que estão sobrepostos. Podem inclusive ser utilizadas com grande potencial de identificação e empatia entre os moradores com o seu patrimônio cultural.

\section{Considerações Finais}

De modo geral, a leitura do material transcrito revela aspectos extremamente ricos para o PIPAG. São memórias que tratam de dois processos que se repetem tematicamente na vida desses moradores: a cidade de Guarulhos como um meio ao mesmo tempo rural e urbano, isto é, ora permeado por lembranças da terra e de seus costumes, ora da industrialização do solo e de desenraizamento; ora das variações que indicam mobilidade compulsória por se tratar de um lugar de busca por melhores condições de vida; ora da fixação e do aprendizado de gostar e de viver no lugar, ou seja, de acolhimento e identificação.

A procissão de escravos que aparecem e desaparecem na estrada ou a sede de uma fazenda que foi assombrada por um escravo são memórias da mobilidade dos sujeitos da terra que aparecem/desaparecem ou que foram expulsos/ fixados nos locais de habitação. Informam para população da região que ali existiu a escravidão, mas também informam seus moradores de que suas casas, ruas e estradas contam a história de sua cidade a partir da identificação coletiva entre diferentes sujeitos no tempo e no espaço.

Os fios narrativos das entrevistas se dão pelos caminhos, pelas estradas, pelos deslocamentos, pela expulsão violenta e pela fixação na terra que marcam a história rural e urbana da região, que podem ser investigados no modo como se deu a ocupação, de seus materiais e estruturas soterradas que deixaram "vestígios de movimentação-fixação”. Por isso, é muito difícil separar os bens materiais e imateriais enquanto objetos de investigação, pois ambos estão presentes na pesquisa arqueológica e na pesquisa realizada pelos historiadores que trabalham com a oralidade e a memória.

GODOY, A.P.; PLENS, C.R. Archeology of Memory from Guarulhos territory.

R. Museu Arq. Etn., 26: 27-41, 2016.

Abstract: The essay presented refers to a teaching experiment as a research in Public Archeology within the Archaeological Heritage Inventory Project of Guarulhos developed from 2012 to 2014. Public Archeology is a branch from Archeology that, even though practiced in different ways, targets at the interlocution between the academic field and the public concerning archaeological interpretation data in a cross-culture dimension. Thus, by the "cross-culturing" amongst Public Archeology, thematic oral history, and recollection, we have attempted to show recollections and the memories of the people of Guarulhos relate to the archaeological traces in terms of conception and reception of the cultural heritage from such territory of the city.

Keywords: Public Archaeology; Thematic Oral History; Memory; Heritage. 


\section{Referências Bibliográficas}

Abreu, R.; Chagas, M. (Orgs.). 2002. Memória e Patrimônio: ensaios contemporâneos. Rio de Janeiro: Lamparina.

Azevedo, F.L.M. de; Catão, L.P.; Pires, J.R.F. (Orgs.). 2009. Cidadania, Memória e Patrimônio: as dimensões do museu no cenário atual. Belo Horizonte: Crisálida.

Cadernos do CEOM/Centro de Memória do Oeste de Santa Catarina. 2007. Educação patrimonial. Chapecó: Argos, 26.

Canclini, N.G. 2009. Diferentes, desiguais e desconectados: mapas da interculturalidade. Rio de Janeiro: UFRJ.

Choay, F. 2001. A alegoria do patrimônio. São Paulo: Estação Liberdade/UNESP.

Costa, C.M. 2008. "A escrita de clio nos temp(l) os da mnemósime: olhares sobre materiais pedagógicos produzidos pelos museus". In: Educação em Revista. Belo Horizonte, n. 47: 217-240.

De Certeau, M. 1994. A invenção do cotidiano: artes de fazer. Petrópolis, RJ: Vozes.

Funari, P.P. 2005. Fontes arqueológicas: os historiadores e a cultura material. In: Pinsky, Carla Bassanezi (Org.). Fontes históricas. São Paulo: Contexto.

Ginzburg, C. 1989. Sinais: raízes de um paradigma indiciário. In: Mitos, emblemas, sinais: morfologia e história. São Paulo: Companhia das Letras: 143-180.

Grinspum, D. 2000. Educação para o patrimônio: Museu de Arte e Escola. Responsabilidade compartilhada na formação de públicos. Tese de doutorado. Faculdade de Educação da USP (FEUSP). São Paulo.
Grunberg, E. 2007. Manual de atividades práticas de educação patrimonial. Brasília, DF: IPHAN.

Horta, M.L.P.; Grunberg, E.; Monteiro, A.Q. 1999. Guia básico de Educação Patrimonial. Brasília: IPHAN/Museu Imperial.

Huyssen, A. 2000. Seduzidos pela memória. Rio de Janeiro: Aeroplano.

Martins, A.L. 2009. Fontes para o patrimônio cultural: uma construção permanente. In: Pinsky, C.B.; Luca, T.R. (Orgs.). O historiador e suas fontes. São Paulo: Contexto: 281-308.

Meihy, J.C.S.B. 2005. Manual de História Oral. 5. ed. São Paulo: Loyola.

Murta, S.M.; Albano, C. (Orgs.). 2002. Interpretar o patrimônio: um exercício do olhar. Belo Horizonte: Ed. UFMG; Território Brasilis.

Perez, C.L.V.; Tavares, M.T.G.; Araujo, M. da S. (Orgs.). 2009. Memória e patrimônios: experiências em formação de professores. Rio de Janeiro: EdUERJ.

Portelli, A. 2001. História oral como gênero. In: Projeto História. São Paulo, n. 22: 9-36.

Portelli. 2010. Ensaios de história oral. São Paulo: Letra e Voz.

Ramos, F.R.L. 2004. A danação do objeto: o museu no Ensino de História. Chapecó: Argos.

Ricoeur, P. 2007. A memória, a história e o esquecimento. Campinas, SP: Editora da UNICAMP.

Santos, B.S. de. 1997. Por uma concepção multicultural de direitos humanos. Revista Crítica de Ciências Sociais, n. 48. 
Silva, V.A. da. 2008. "Paulistas em movimento: bandeiras, monções e tropas". In: Setúbal, M. A. (Coord.). Terra paulista: A formação do Estado de São Paulo, seus habitantes e os usos da terra. São Paulo: CENPEC/Imprensa Oficial:. 55-101.

Soares, A.L.R.; Klamt, S.C. (Orgs.). 2007.

Educação patrimonial: teoria e prática. Santa Maria: UFSM.
Todorov, T. 2000. Los abusos de la memoria. Barcelona: Paidós.

Urry, J. 2001. O olhar do turista: lazer e viagens nas sociedades contemporâneas. 3.edição. São Paulo: Studio Nobel: SESC.

Zanirato, S.H. 2009. Usos sociais do patrimônio cultural e natural. In: Patrimônio e Memória. UNESP - FCLAs - CEDAP, v. 5: 145-60. 